\title{
Non-Metastatic Extraskeletal Osteosarcoma
}

National Cancer Institute

\section{Source}

National Cancer Institute. Non-Metastatic Extraskeletal Osteosarcoma. NCI Thesaurus.

Code C8809.

Osteosarcoma that arises from the soft tissue and is confined to the site in which it initially manifested. 